Forthcoming, Archives of European Sociology, 2001

\title{
Trust, Honesty, and Corruption: Reflection on the State-Building Process
}

\author{
Susan Rose-Ackerman 1
}

\section{Introduction}

Trust implies confidence, but not certainty, that some person or institution will behave in an expected way.2 A trusting person decides to act in spite of uncertainty about the future and doubts about the reliability of others' promises. 3 The need for trust arises from human freedom. As Piotr Sztompka (1999: 22) writes, "facing other people we often remain in the condition of uncertainty, bafflement, and surprise."

Honesty is an important substantive value with a close connection to trust. Honesty implies both truth-telling and responsible behavior that seeks to abide by the rules.4 One may trust another person to behave honestly, but honesty is not identical to trustworthiness. A person may be honest but incompetent and so not worthy of trust. Nevertheless, interpersonal relationships are facilitated by the belief that the other person has a moral commitment to honesty or has an incentive to tell the truth. Corruption is dishonest behavior that violates the trust placed in a public official. It involves the use of a public position for private gain.

1Henry R. Luce Professor of Law and Political Science, Yale University. The comments of János Kornai and Margaret Levi are gratefully acknowledged. Derived from a longer paper prepared for the Workshop on Honesty and Trust in Post-Socialist Societies at Collegium Budapest, May 25-26, 2001. A publication, based on another part of the background paper is "Trust and Honesty in Post-Socialist Societies," Kyklos 54: 407-435 (2001).

2Russell Hardin's (2001: 10) view that trust is a type of knowledge or belief, not an action, seems correct although in practice all one may be able to observe is the action that follows.

3Sztompka (1999: 25-40), Dasgupta (1988: 51). As Annette Baier (1986: 235) writes: "Where one depends on another's good will, one is necessarily vulnerable to the limits of that good will. One leaves others an opportunity to harm one when one trusts, and also shows one's confidence that they will not take it." Diego Gambetta characterizes trust as follows. "Trust (or, symmetrically, distrust) is a particular level of the subjective probability with which an agent assesses that another agent or group of agents will perform a particular action, both before he can monitor such action (or independently of his capacity ever to be able to monitor it) and in a context in which it affects his own actions... When we say that we trust someone or that someone is trustworthy, we implicitly mean that the probability that he will perform an action that is beneficial or at least not detrimental to us is high enough for us to consider engaging in some form of cooperation with him" (Gambetta 1988b:217).

4For a discussion of lying see Bok (1978). 
I focus on honesty and trust as they affect the functioning of the democratic state and the market. I am interested in informal interactions based on affect-based trust only insofar as they substitute for, conflict with, or complement the institutions of state and market. The relationship between informal connections and formal rules and institutions is my central concern. The institutions of interest are democratic political structures, bureaucracies, law and the courts, and market institutions.5

As Mark Warren points out, governments are needed in just those situations in which people cannot trust each other voluntarily to take others' interests into account. The state is a way of managing inter-personal conflicts without resorting to civil war. Yet, this task is much more manageable if the citizenry has a degree of interpersonal trust and if the state is organized so that it is trusted by its citizens, at least, along some dimensions. The state may be able to limit its regulatory reach if interpersonal trust vitiates the need for certain kinds of state action (Offe 1999). Conversely, if the state is reliable and even-handed in applying its rules, that is, if people trust it to be fair, state legitimacy is likely to be enhanced (Offe 1999, Sztompka 1999: 135-136).6 Thus, there are three interrelated issues. First, do trust and reliability help democracy to function, and if so, how can they be produced? Second, do democratic governments help create a society in which trustworthiness and honesty flourish? Third, given the difficulty of producing trustworthiness and honesty, how can institutional reform be used to limit the need for these virtues?

This paper provides a framework for thinking about these broad questions. Section I organizes the research on trust especially as it applies to the relationship between trust and government functioning. With this background, section II discusses the mutual interaction between trust and democracy. The alternative of limiting the need for trust leads, in section III, to a discussion of corruption in government and commercial dealings. Corruption occurs when dishonest politicians and public officials help others in return for payoffs. Because their actions are illegal, they need to trust their beneficiaries not to reveal their actions. Corrupt officials are also, of course, betraying the public trust insofar as their superiors are concerned. Reforms here can involve a reorganization of government to limit the scope for lucrative discretionary actions. Conversely, one might focus on changing the attitudes of both officials and private actors so that existing discretion is exercised in a fairer and more impartial manner.

This paper analyzes the interactions between trust and democracy at a general level. However, its initial aim was to provide a context for a workshop at the Collegium Budapest on honesty, trust, and corruption in post-socialist countries. My companion paper in Kyklos makes that link explicit by bringing in survey evidence on public attitudes and behavior. Here, I conclude in section IV with some thoughts on the special character of the transition process. I highlight the tensions between interpersonal trust and trust in public institutions in the context of the transition to democracy and a market economy.

5 Excellent introductions to work on the link between government and trust are Braithwaite and Levi (1998) and Warren (1999a).

6Hardin $(1998,1999)$ argues that it is incoherent to speak of trusting a state institution, but that is because he only considers what I call below "reputation-based trust". 


\section{Generalized Trust, Reliability, and Reciprocal Trust}

Many claim that societies cannot function without high levels of trust.7 Sometimes this claim is coupled with a lament about the decline of trust in the modern world and nostalgia for the days when trust was high and personal involvement in civic life was pervasive. Sometimes the discussion proceeds as if "trust" in and of itself is valuable as evidence of close interpersonal links. Trust and a strong "civil society" are taken to be synonymous. But disembodied trust is not a very meaningful normative concept. It is parasitic on other underlying substantive values and cannot be evaluated and studied except in context.8 The values I emphasize are increases in individual wellbeing and the creation of states viewed as legitimate by their citizens. Trust is an input into the processes of economic growth and state-building that may have negative as well as positive consequences (Putnam 2000: 350-363, Hardin 2001, Rose-Ackerman 1999: 96-99).

Although I begin with generalized trust, my main concern is relational trust -- that is, trust in particular contexts, whether one-sided or reciprocal. Although it may be true, as Eric Uslaner (2000-2001) argues, that generalized trust in others has deep roots in individual psychology and upbringing, structural conditions are, nevertheless, important in influencing trust and behavior in particular cases. The tension between trust based on interpersonal empathy and trust based on neutral fairness is my central analytic and empirical concern.

One uninteresting class of cases can be eliminated from consideration right away - simple probabilistic calculations based on natural, physical phenomena, as when someone says: "I trust the sun will rise tomorrow", or "I trust that the seeds that I have planted will germinate if the weather is favorable." There is no reliance on human agency here. In fact, although such usage is common, it is misleading to refer to "trust" in this context. One is simply making a prediction based only on one's knowledge of the natural world, and it would be clearer to speak in those terms.9 Let us turn then to situations that depend on human decisions whether or not to act in a trustworthy manner.

\section{Generalized Trust and "Social Capital"}

Generalized trust in others has recently been measured extensively and used as an indicator of the health of society. This type of trust expresses a background psychological attitude rather than trust in identifiable others to do particular things (Hardin 2001). Such measures of trust are very difficult to interpret and to translate into concrete proposals. The causal links between measures of generalized trust and the performance of government and market institutions are not always wellspecified and the empirical tests are inconclusive.

7"In almost trivial ways, without trust the most basic activities of everyday life would become impossible" (Warren 1999b:2). See also the sources cited in Sztompka (1999: ix).

8As Gambetta (1988: 214) states: "A priori, we cannot always say whether greater trust and cooperation are in fact desirable." He evokes the example of a group of robbers and murderers who operate on the basis of interpersonal trust. Gambetta's (1993) own study of the Italian mafia is full of relevant examples. See also Sztompka (1999: 114-115).

9Gambetta (1988: 218); Luhmann (1988); Sztompka (1999:19-21). 
Generalized trust is not the same thing as "social capital." The issues of trust and social capital have received considerable attention because of Robert Putnam's $(1993,2000)$ claim that when social capital is high, citizens express confidence and trust not only in each other but also in public institutions. According to him, this encourages citizens to work to improve the democratic accountability of the state. Putnam argues that strong "civil societies" generate interpersonal trust and tolerance that is transferable from the voluntary organizations and groups that produce it to the broader framework of democratic participation. Under this view, which conflates generalized trust and social capital, societies need to create opportunities for social capital to be produced through voluntary activity based on friendship, loyalty, or commitment. Putnam believes that trust created at that level will aid in the production of the generalized trust useful for the maintenance of a stable democracy.

There appear to be serious problems with Putnam's conceptual framework. The available evidence does not demonstrate a strong link either between trust in people within a particular organization and generalized trust in others or between generalized trust and trust in state institutions. In 1990 and 1996\1997 the World Values Survey (WVS) asked whether, generally speaking, "most people can be trusted" or whether "you can't be too careful in dealing with people" (Inglehart 1997:399). Generalized trust is associated with stable democracies according to research based on the WVS. In a multi-variate analysis based on 41 cases worldwide, the number of continuous years of democratic functioning between 1920 and 1995 is positively associated with high levels of interpersonal trust as well as with GNP/per capita and expressions of well-being (Inglehart 1997: 183, see also Inglehart and Baker 2000). Although this finding suggests that generalized trust and democracy reinforce each other, it does not imply that the development of generalized trust will generate strong democracies.

Work by Eric Uslaner (2000-2001) concludes that participation in voluntary institutions does not produce generalized trust in others and does not promote democracy. In fact, when one takes account of the simultaneous equation nature of the problem, involvement with church groups actually tends to decrease generalized trust although volunteering and charitable giving do have a positive influence. He also finds some degree of reverse causation. More trusting individuals are more likely to be involved in business and cultural groups and more likely to volunteer and make charitable contributions. Conversely, Uslaner finds that democracy does not generate trust even if the two are correlated. Along the same lines, membership in voluntary organizations played no independent role in determining the durability of democracy according to Ronald. Inglehart (1997: 183, 188-194). Work by Dietlind Stolle $(1998,2001)$ also counsels caution. Stolle's survey work in Philadelphia, Berlin and Stockholm shows that the length of time spent participating in a particular organization did seem to build up "private social capital" between members of the organization. However, there was little or no spillover into general social capital as measured by generalized trust or civic engagement. In Sweden the result for some organizations was even negative. Stolle also claims that self-selection can explain why some organizations, for example, church choirs, seem to be composed of people who have high levels of general social capital. In research that is somewhat more supportive of Putnam's claims, John Brehm and Wendy Rahn (1997) demonstrate, with individual-level US data, that the causation runs weakly from interpersonal trust to both civic engagement and confidence in government but much more strongly from both confidence in government and civic engagement to interpersonal trust. 
Further reason for skepticism about the causal relationship from trust in others to trust in government comes from work on generalized trust in the post-socialist countries. Levels of generalized trust are not particularly low. For example, in 1998, 51\% of those surveyed in Central and Eastern Europe by the New Democracies Barometer said that most people can be trusted; in $2000,66 \%$ of Russians agreed, up from $34 \%$ in 1998 . These replies were below the $77 \%$ figure for Korea, but they are above recent United States numbers which are hovering at about 35\%. There does not appear to be a drastic deficit in interpersonal trust in the region (Rose and Haerpfer 1998a: 62-63, Rose 1999: 13, Rose and Shin 1998:16-18, Rose 2000:29, Uslaner 2000-2001). However, trust in others does not necessarily translate into trust in government. In 2000, Russians expressed high levels of distrust in all institutions except the army and the president (Rose 2000: 28-29). Looking across the countries surveyed in the New Democracy barometer, Ukrainians who have low levels of trust in government institutions express a high degree of trust in "most people you meet." In Central Europe, the most distrustful of other people are the Romanians and the Bulgarians, but their views of a range of institutions are not markedly different from those of their neighbors. Thus, there are some countries where interpersonal trust is high and trust in institutions is low, and some where at least some institutions are trusted although inter-personal trust is low (Rose and Haerpfer 1998a: 62-63).

Growing interpersonal trust does not necessarily translate into democratic benefits. This is likely to be particularly true in post-socialist societies where appeals to support the "collective good" are often viewed with skepticism (World Bank 2000b: 199). My critique of Putnam should not, however, be read as a general critique of the concept of social capital and its role in economic and political development. Rather, I would argue for a more nuanced view that does not treat social capital as an undifferentiated mass that is "produced" by participation in voluntary groups. Instead, one needs to understand the different kinds of interpersonal links that develop between people as a result of their personal and organizational ties. Then, one could study the way specific types of private organizations and groups influence people's interactions with the state and the market. Such research could lead to proposals for policies that might facilitate the growth of civil society and social capital, but that would not necessarily promote generalized trust.

There seems no reason to assume that a legitimate state will bubble up spontaneously as people become more trusting of those they meet. Nongovernmental organizations may have important benefits for those concerned with state-building. This connection, however, does not depend on the claim that such institutions increase generalized trust. First of all, they may not do so, and second, even those that do, may not generate large benefits in terms of civic engagement.10

\section{One-Sided Reliability}

Moving from generalized trust in others to specific human and organizational interactions, requires more articulated models. I emphasize the basic distinction between one-sided reliability or confidence and two-sided or reciprocal trust. Under some conditions, these alternative types of trust can operate at cross-purposes.

10 See the end of section III.2 for a discussion of the role of nongovernmental organizations in the state-building process that stresses their role in monitoring the state. 
Under "one-sided reliability" person A decides whether or not to trust another person or institution, $\mathrm{B}$, on the basis of information about incentives, motives, and competence. The situation is one-sided in that the trusted person is uninterested in whether A is trustworthy.11 B may, however, be influenced by A's expected reactions to B's actions. The situation may involve strategic interactions, but only one of the actors must decide whether to be trustworthy, and only one has to decide whether or not to trust. I distinguish three types of one-sided reliability.

A first is reputation-based trust that arises from one's belief that the other can be trusted because it is in his or her interest (Sztompka 1999: 71-72, Wintrobe 1995: 46). Russell Hardin $(1998,1999)$ calls this "encapsulated interest". A reputation for trustworthiness is beneficial to the individual. In much economic analysis of the topic, trust and honesty grow out of repeat play. The business person is trusted, not because he appears especially moral or good, but because it is in his interest to be viewed as reliable.

If morally good people can credibly signal their character, they have a competitive advantage because they find it easier to convince people that they should be trusted. However, if there is a scarcity of such people, trustworthy reputations can also be developed by the purely selfinterested. If information about the outcome of particular transactions is communicated to the world at large, each deal creates spillovers. A seller may act in a trustworthy way, not just to induce the particular buyer to return, but also to send a signal to other potential buyers (Sztompka 1999: 104).

Such a process, in which self-interested people act in a "good" way, has particular appeal for economists who defend the market as a welfare-enhancing institution in which all actors are self-interested. In these models, actors have an incentive to establish a good reputation irrespective of what other economic actors are doing. If they charge the same price, a trustworthy seller will always get more business than an untrustworthy one. The only reason for failing to develop a trustworthy reputation is the cost of communicating one's type to the customer base. There is no need for external law enforcement.

Models of this type may be strategic in that B's incentive to be trustworthy depends on estimates about the behavior of A, who, in turn, bases her behavior on a estimate of B's actions.12 Consider, for example, the well-known problem illustrated by the used car market. George Akerlof (1970) argues that because consumers are poorly informed, sellers have an incentive to try to sell low-quality cars, "lemons," by passing them off as high-quality cars. This will drive high-quality cars from the market if sellers cannot credibly commit to automobile quality. Customers anticipate this behavior of sellers and will not believe any one who claims to be selling a high-quality car. Then, the only cars that change hands are of low quality. A business person who could establish a credible reputation as a seller of high-quality cars could make money. He might do this over time as satisfied customers report their experience, but he would need some device, such as a moneyback guarantee, to get his business started. Alternatively, if he can credibly signal his high integrity ex ante, he can successfully enter the market. This is an example of trust as one-sided reliability in a strategic context. The seller anticipates the buyer's behavior, but the buyer is the only one who

11 This category is similar to Sztompka's (1999:27) concept of "anticipatory trust."

12The cases that Hardin (2001:17-18) discusses are mostly of this sort and derive from conditions that approximate the prisoners' dilemma. 
needs to exhibit trust. Below I consider strategic cases where trust is a two-sided affair.

A second, related, type of one-sided reliability is trust in a professional with specialized knowledge such as a doctor or lawyer or a scientific expert who predicts the future or who predicts the result of engaging in some risky activity, such as taking a prescription drug or breathing an air pollutant (Barber 1983, Sztompka 1999:46-48). Just as in the first case, one needs to know if the person's material incentives are aligned with one's own interest in the truth or in reliable service. However, also of importance are the expert's competence and reputation for unbiased judgment. She is trusted both because she is highly skilled and because she holds professional norms that value trustworthy behavior and truth telling. These norms should dictate honest reporting of scientific tests even if they are contrary to the expert's expectations. The professional norms of lawyers and doctors should induce them to act in the interests of their clients and patients. Trust is one-sided here because, although those who rely on the expert must trust her, the expert, herself, is uninterested in the trustworthiness of those who use her predictions and services. The exception here would be a provider of professional services who cares about her clients' reputations for paying their bills

In the United States there appears to have been a decline in public trust in scientific experts. According to Paul Slovic, lack of trust underlies a number of recent controversies over technological hazards (Slovic 1993). For example, the risks of nuclear waste disposal and exposure to chemicals are viewed as unacceptably large by ordinary people even though experts evaluate the risks as low and comparable to risks that people do accept. The problem is not a failure to communicate the relevant data but a lack of public trust in its reliability (ibid.:676). In this area, trust is fragile since a single, highly visible, negative instance can undermine trust in experts' claims. Furthermore, the public views the sources of trust-destroying news as more credible than those that provide news that reinforces trust. A negative piece of news can lead one to interpret subsequent information in a negative light thus amplifying the effect over time (ibid.: 678-679). One solution is to limit public participation. In France the public perceives the risks of nuclear power to be high but trusts the state to manage these risks even though it accepts little public input. This is not an acceptable solution for more participatory systems such as the United States. Instead, Slovic tentatively recommends more power sharing and public participation that goes beyond public relations (ibid: 680). He claims that trust built on democratic participation will help increase the credibility of science in policymaking.

The third type of one-sided model is not tied to individual motivation, but to organizational functioning.13 This is rule-based trustworthiness - that is, trust that an organization's rules will be followed in a neutral and predicable way. One trusts the institution's rules irrespective of the particular people occupying positions of trust and authority. It is easy to see why those at the top of an organization might want to create such standards, but it is less clear how inferior officers can be induced to behave in a rule-bound way. There are several potential problems. First, how easily can one find out ex post if the official or employee acted badly? Are there other intervening variables, so that a poor outcome does not necessarily imply that the expert acted badly? Second, if monitoring is possible, can costs be imposed? Third, how costly is it to monitor and to impose costs? When the answers to these questions are unfavorable, the solution may be to reduce the

13Sztompka (1999:44) calls this "procedural trust." 
human element in administration. One might simply limit the conditions under which trust is needed (Gambetta 1988: 220, Levi 1998).

As Niklas Luhmann (1988: 99-105) points out, social evolution toward increasingly complex societies may increase the benefits of trust in public agents at the same time as it undermines trust based on family and friends. Hierarchies of agencylprincipal relations expand the scope of organizations and permit the use of specialists. The functioning of these organizations is closely related to the reliability of these agents. Even without hierarchy and specialization, trust can facilitate arms-length activities organized over space and time or indeed any activity in which monitoring is costly.14

\section{Reciprocal Trust}

Now consider "reciprocal trust." Frequently, all participants are affected by the attitudes and expected behavior of those on the other side of the transaction. These cases differ from the strategic interactions listed above in that people have a reciprocal relationship based on trustworthiness. Trustworthy behavior can be affected by one's guesses about the trustworthiness of others. The links may be based on mutual calculations of the others' interests, on feelings of personal affection and responsibility, or on shared values (Gambetta 1988: 230-231, Hardin 2001). Because links of trust between two people can inflict harms or benefits on others, the discussion of honesty and trust needs to be embedded in the institutional structures in which people deal with each other.

First, as Russell Hardin (2001) argues, mutually reinforcing trust can be interest-based. All that is required is to take a situation where encapsulated interest operates on one side of the transaction and graft it onto another where trust flows the other way. Reciprocal trusting relationships may involve individuals with very different degrees of power and with very different aims. Even in a hierarchical relationship where a principal (superior) requests an agent (inferior) to do something, trust does not flow only from the trusting superior to the trustworthy agent. Rather the agent also trusts the superior to carry our her side of the bargain by, for example, paying him when the job is done. When economic relationships are organized over time, A, the one who acts first, may trust B, the second mover, to act as promised, or A may write an enforceable contract that reverses the burden of trust. For example, A may require B to give him something of value to hold as a hostage against B's performance. B will not do this, however, unless he trusts A not to abscond with the hostage. In many relationships, the unfolding of interactions over space and time means that people shift from being the one who trusts to being the one who is trustworthy and back again. Over time, the very act of trusting may induce the other person to be more trustworthy, and so on in a benevolent spiral. Conversely, showing a person that he is distrusted may cause him to confirm your expectations (Sztompka 1999: 28, 61-62, 106).

Second, reciprocal trust can be a reflection of warm personal feelings. People may trust others because they believe that the others wish them well. However, one needs to recognize that

14Nicholas Luhmann $(1979,1988: 99)$ emphasizes how trust in strangers who are part of institutions can help coordinate activities over space and time in a way that permits complex, differentiated societies to function. 
close personal relations can engender hatred and jealousy as well as love and affection, and sometimes the latter can turn into the former. Distrust is sometimes pervasive in close-knit communities that give people little possibility of exit (Levi 1998:82-83). Furthermore, trust in a network of close kin or ethnic group members may reduce trust in outsiders (Wintrobe 1995).

Third, reciprocal trust can reflect shared values and goals, not empathy. People trust each other because they have a common belief in the moral value of cooperative and helpful behavior (Braithwaite 1998). Trust motivated by moral values, such as respect, may be extended altruistically (Mansbridge 1999). This type of trust can reinforce the legitimacy of public institutions and overcome cooperation problems such as the prisoners' dilemma under which those who anticipate the self-interested behavior of others behave in a self-interested way as well. A person may cooperate, not only because she views cooperation as good, but also because she believes that you share her belief. The key is not trust per se but a mutually trusting relationship.

However, reciprocal trust can generate patterns of behavior that actively undermine state functions. This can be viewed as positive or negative depending upon one's evaluation of the state. On the one hand, close-knit criminal groups may create networks based on a mixture of empathy, threats, and shared goals that leave the police powerless (Gambetta 1988: 214, 1993). On the other hand, organizations based on interpersonal solidarity in the face of an illegitimate state can sow the seeds of revolutionary change. Such groups were important in setting the stage for the fall of the socialist states in Central Europe although they obviously could not have achieved the change entirely on their own (Sztompka 1999: 151-160, Warren 1999b: 12-14, World Bank 2000b:118).

If cooperation is fragile and subject to breakdown, one option is to develop strategies that minimize trust (Levi 1998). Thus Robert Axelrod (1984) showed that a strategy called "tit for tat" performs best against other strategies in a repeated prisoners' dilemma game. Under that strategy, a player cooperates in the first round, but if the other player opts not to cooperate, the first player fails to cooperate in the next round and continues to play that strategy until the other player opts to cooperate. When he does, the first player cooperates in the next round and so on. This strategy requires no trust at all. A player simply communicates his intentions clearly by the moves he makes, but the result can be to establish long-term cooperation. Nevertheless, the strategy may be more effective if the tit-for-tat player announces his strategy up front and if the other player trusts his credibility (Gambetta 1988: 222-229). Notice that the tit-for-tat player wants the other player both to trust that cooperation will be met by cooperation and that failure to cooperate will be swiftly punished. A person with too strong a reputation as a cooperator might not be able to develop a credible reputation for retaliation: the other player trusts him to cooperate but does not trust him to inflict punishment.

Now consider interactions between large numbers of people with no collective organization. If reciprocity is based on moral motivations, the overall level of trustworthiness and honesty can be affected by the proportion of others who are also trustworthy and honest. If a high proportion of actors is trustworthy and honest, this will encourage others to become honest, and so on until all but a few diehards are honest. Conversely, if most are distrustful and dishonest, even more shift in that direction, until all but the moralists are lying and cheating. Moral qualms are not absolutes but are affected by one's perception of what others are doing (Fehr and Gächter 2000; Sugden 1984).

A similar dynamic can operate if behavior depends on the chance of being caught behaving in a dishonest or untrustworthy way. In one version of this model, the monitoring process breaks 
down as the proportion of cheaters increases. One's behavior is affected by the trustworthy or honest behavior of others, but one's motivation is pure self-interest. In another version, one's expectations about those on the other side of the transaction are key. You will be more likely to offer a bribe if you expect that most officials are corrupt. Then, even the formerly honest will be offered bribes, and some may become corrupt when offered the opportunity. If you think most are honest, you will be deterred from offering a bribe for fear of being arrested and hence few potentially corrupt officials will actually accept bribes, leading them to turn honest as well. Similarly, a person may behave in a trustworthy way toward his family members if they reciprocate, but revert to feuding if they cheat or undermine him.15 A spiral in which distrust breeds more distrust can be particularly destructive in complex societies. A decline in confidence or an increased difficulty of finding others who warrant trust can unleash a deteriorating cycle that diminishes the range of activities that people are willing to carry out.

These dynamic models appear consistent with Putnam's (2000) view of the decline of generalized trust in the United States. Putnam's analysis, however, takes insufficient account of strategic considerations. People who express high or low levels of generalized trust may trust others in one strategic context, say involving neighborhood cooperation in a common task, and distrust others in another, say in deciding whether to pay taxes or apply for a scarce public benefit. In these dynamic models there is no generalized "social capital." Instead, behavior is a function of the particular situation, including estimates of the probable behavior of others.

\section{A Typology and a Tradeoff}

Research on trust can be organized in terms of the interrelationships between people, on the one hand, and the origin of individual trusting or distrusting attitudes, on the other. I make a preliminary attempt to isolate the most important factors here, but my framework is designed to promote discussion, not set up rigid categories.

Consider, first, the interpersonal dimension. I have isolated three broad categories:

1) Generalized trust: One's trust in others is part of a general attitude, not an evaluation of the particular, interpersonal situation. Its origins, however, may lie in a person's past experiences of one-sided reliability or reciprocal trust.

2) One-sided reliability: Individual A's trust in a particular person, B, depends upon an estimate of B's trustworthiness. B's trustworthiness, however, is independent of A's own trustworthiness. However, B's behavior may be influenced by reactions of those on the other side of the transaction and by the costs of monitoring and control.

3) Reciprocal trust: Trustworthy behavior is influenced by the degree of trust and trustworthiness expressed by others. The relevant others may be (i) the people one deals with directly who are on the other side of the transaction, or (ii) others similarly situated such as other firms in the same industry, fellow public officials, or other applicants for scarce public services.

The second dimension involves the process by which trust is generated either through repeated interactions or through psychological or moral attitudes. I have isolated five broad categories, but they are not mutually exclusive. Several can co-exist at once. In that case, it will be

15Some of these models are summarized in Rose-Ackerman (1999: 107-108, 124-125). 
important to determine which reinforce each other and which operate at cross purposes. These categories interact with the interpersonal alternatives above although some appear to be more closely associated with one than with another. The five categories are as follows.

a) Encapsulated interest: Trustworthy behavior that develops over time as a part of people's efforts to develop a reputation for reliability. Of course, such a reputation must be valuable so that the interest of customers or citizens in reliability influences the decision to supply it. This can produce one-sided trust when a feedback loop operates that is tied to the actor's narrow selfinterest. Alternatively, in the two-sided case, interest-based trust can develop in which actors have an instrumental incentive to act in a trustworthy manner to further other goals. These other goals might be economic, political, or moral but are distinct from trustworthiness per se. An important empirical issue is whether trust developed out of encapsulated interest can produce generalized trust in others.

b) Expert-based: Trust in experts who make predictions or provide services based on science or other forms of professional expertise. This will be mostly one-sided trust in which ordinary people trust experts, but the experts, in turn, have no interest in the trustworthiness of ordinary people.

c) Rule-based: An organization is trusted because it promises not to deviate from clearlystated procedures that treat people neutrally. This is one-sided trust in an institution, but if that institution is the state, its trustworthy reputaton can make people more willing to trust anonymous others.

d) Affect-based: Trustworthy behavior is encouraged by love and friendship. This could involve a one-sided relationship, or it could be influenced by the vulnerability and trust of those who depend on you because of ties of kinship and affection. In other words, the other person need not be trustworthy, but his or her trust in you influences your behavior.

e) Morality-based: Beliefs in the trustworthiness of others are reinforced by interactions with others who have moral commitments to act in a trustworthy way, and vis versa if others are untrustworthy and dishonest. Moral behavior may be motivated by the impact on third parties not part of the transaction. Generalized trust may be the result of interactions over time with others who believe that trust is morally right.

This way of organizing the concept of trust can help one isolate tradeoffs, conflicts, and complementarities between alternative types of trust and trustworthiness. The most obvious tension is between reciprocal trust and one-sided trust in the fairness of public institutions and markets. Interpersonal trust based on empathy and a sense of duty toward family and friends is quite different from trust in the fairness and neutrality of officials and institutions that govern modern complex societies. 16

In complex societies, one-sided trust based on reliable predictions is especially important. Unfortunately, reciprocal trust based on personal connections may operate at cross-purposes to trust as reliability. Organizational designers and legal reformers frequently seek to create systems that operate fairly and without favoritism. This goal can conflict with reciprocal, affect-based trust

16Claus Offe (1999) distinguishes between expectations of reciprocity in interpersonal trust and trust in institutions on the basis of knowing that its rules, values, and norms are shared by participants who view them as binding. 
that depends upon close personal relations or kinship. One who relies on affect-based trust may believe that the trusted person will favor her whether or not she fulfills the formal qualifications and will aid her even if it imposes some costs on him in his institutional role. In a world where affect-based trust is dominant, there may be little trust based on the notion of trust as reliability. The development of a modern, complex society may be stifled.17

Even trustworthy and honest behavior that is motivated by moral beliefs, not kinship ties, may undermine some kinds of rule-based systems. Superiors in an organization may want clear, neutral rules that ignore individual circumstances. The official who is motivated by his own moral beliefs may be just as harmful to efforts to construct a rule-based system as the one who favors his nephews. A person who follows his ideological or religious beliefs no matter what role he plays can undermine efforts to develop trust in public institutions through promises of rule-based service delivery.

Conversely, a credible background of rules can encourage interpersonal trust. Once these trusting relationships are established, the participants are less dependent on the background rules, but such relationships would have been difficult to establish in the absence of rules. One role of the law is to facilitate the development of reputations over time by providing a backstop for private dealings. Thus, an important issue is whether private order is a complement or a substitute for public order. In one empirical exploration of this issue, John McMillan and Christopher Woodruff (2000: 31,39) find that in Central and Eastern Europe social networks and reputation are a substitute for effective courts, but that business networks function better when the legal system is viewed as a viable option to resolve disputes. A background institution for dispute resolution lowers transactions costs and encourages firms to expand their range of business dealings beyond a narrow circle. Well-functioning courts help keep the market open to new entrants and permit trade to occur with strangers. However, over time, ongoing business relationships are maintained by the trust that comes from repeated interactions.

\section{Trust and Democracy}

Large democracies govern themselves through political representatives and other kinds of agents such as bureaucrats and judges. Because elected representatives cannot be perfectly

17Inter-personal trust based on ethnic group membership may exclude non-members and make exit all but impossible. In the inter-generational context, the trust that parents place in their children comes from the shame and guilt that children feel as a result of pressure not just from parents but from other members of the ethnic group. A society divided into a collection of ethnic groups may operate with little cross-ethnic economic and social activity thus limiting social and economic development. Ethnic groups might make it easy to develop a trustworthy reputation and impart useful social values that maintain social order, but they can also create prejudice and hostility among groups (Wintrobe 1995)). For example, the risks of kin-based trust are illustrated by a detailed study of two Northern Albanian villages. In one village five extended families dominated village life and cooperation across kinship lines was limited. In the other, family groupings were less powerfully entrenched and community-wide cooperation was possible and successful (World Bank 2000b: 199, 203; the Albanian study is by Douglas Saltmarche). 
controlled by voters, the electorate must have some level of trust in those it elects. Similarly, bureaucrats and judges also have considerable discretion. The more they can be trusted to fulfill their roles willingly, the fewer the resources needed to monitor and discipline them, and the more discretion they can be given. The key requirement here is for one-sided trust based on the reliability or trustworthiness of public officials.

Piotr Sztompka (1999: 146-148) lists the ways in which trust contributes to democracy. The most important omission from his list, in light of my framework, is reciprocal trust based on kinship, love, and friendship. Although he does not explicitly deal with the downside of this type of trust, the omission is consistent with my own emphasis on the tension between friendly reciprocity and legitimate democratic functioning. According to Sztompka, democracy requires communication, and trust facilitates communication by helping people both to speak and to listen. Democracy requires tolerance of difference, and trust in others is part of accepting differences rather than seeing them as threats. Mutual trust keeps public debates from degenerating into personal attacks. These three claims depend on reciprocal trust that derives from moral commitments. Sztompka also argues that democracy requires people to accept some basic rules of interaction. Trust in others makes people more willing to play by the rules since they anticipate that others will do so as well. People need to trust both public institutions and other people in order to be willing to participate in politics. These two aspects depend upon the rule-based character of the state, that is, on its reliability or trustworthiness. To the extent that one trusts other people, it is because they operate under the same set of rules, not because of love and friendship. Finally, people need information in order to be responsible citizens, and in this connection, they need to be able to trust the sources that provide this material. This is one-sided trust in expertise. Thus, the link between trust and democracy is multi-dimensional, and an increase in trust along one line, say in the reliability of the information provided by the media, has no necessary spillover benefits for other dimensions.

To complicate mattters further, causation may run in the opposite direction from democracy to trust. Some claim that a well-functioning democratic government can create interpersonal trust (Warren 1999c; Rothstein 2000a, 2000b; Levi 1998: 85-94; Stzompka 1999: 139-146; Cohen 1999). To Piotr Sztompka, democracy imposes credible constraints on politicians and public officials. Trust is then a rational response, not a result of "blind" loyalty, and permits people to take risks in dealing with each other in both the political and the economic sphere. "The more there is institutionalized distrust, the more there will be spontaneous trust" (Sztompka 1999: 140). When these constraints collapse, an inverse case can occur, where distrust and recrimination generate more of the same in the next period leading to a deterioration of state legitimacy and functioning and a breakdown of economic relations that depend on a reliable legal and political system.

"Government" is too undifferentiated a concept to be analyzed as a whole. One needs to consider the trustworthiness and honesty of elected politicians and other political actors, of bureaucrats up and down the civil service, and of the judiciary. A competitive electoral process can give politicians an incentive to reveal the untrustworthy behavior of their opponents and to be trustworthy themselves. One problem here is the possible tension between keeping one's promises to campaign contributors and powerful interest groups, on the one hand, and representing the interests of ordinary citizens, on the other. 
Jean Cohen (1999) and Margaret Levi (1998) emphasize the importance of governmental institutions in effecting a shift from a low-trust trap to a more functional situation. Like Sztompka, Levi focuses on the fair and transparent operation of government, in other words, its rejection of affect-based trust in its dealings with citizens. According to Levi, most important are "the capacity to monitor laws, bring sanctions against lawbreakers, and provide information and guarantees about those seeking to be trusted" (Levi 1998:85). In her work, the focus in not so much on democratic electoral structures as on bureaucratic and legal institutions that make government transparent and fair. These institutions should be designed so that officials have an interest in behaving in an honest and trustworthy way (ibid.: 87). Then, there may be a positive feedback loop between interpersonal trust and trustworthy government. Levi draws a useful distinction between the government's credible commitments and fair procedures, on the one hand, and citizens' feelings of ethical reciprocity, on the other. People are more likely to comply with the rules set down by the state if they think the rules will be enforced in an evenhandedly way. Compliance is also enhanced by the belief that others are also obeying the rules (ibid.: 87-93). The trustworthiness of government encourages widespread compliance with the rules. In the next iteration, even more people comply because they are influenced by the widespread compliance of others.

Bo Rothstein (2000a, 2000b) accepts the self-reinforcing nature of well-run governments and interpersonal trust, but he argues that purely institutional changes will be insufficient. Rather, he draws on work on "collective memory" to argue that policymakers ought to engage in a process that makes creative use of a country's history to emphasize precedents that support trust both in the state and in other people. He urges that culture and history not be taken as arguments for accepting a low-trust status quo. But, instead, he urges a political dialogue about the nature of a nation's collective memory as part of the process of reform.

Along the lines of Rothstein's proposals, Charles Sabel (1993) presents a case in which trust was generated in a formerly distrustful environment through a process that redefined the actors' identities. The case involved efforts to revitalize the garment, foundry, injection-molding, and machine-tool industries in particular regions of the Commonwealth of Pennsylvania. Sabel develops the notion of a "reflexive self" who "can entertain and act on the idea of creating or extending common values regarding loyalty and forbearance in the face of vulnerability precisely because it knows that other selves can entertain and act on the same idea" (ibid.: 1142). In the process of building trust, the actors "create a past in which prior conflicts resulted from mistakes and misunderstandings rather than fundamental differences" (ibid.: 1146). In the Pennsylvania cases, the key was the development of networks of local people who worked together to propose solutions. In spite of industrial histories of competition and conflict, many of these people had worked together cooperatively on other projects in the past and this background was used to develop a sense of community membership.

Nevertheless, one should not under-emphasize the difficulty of the policies that Rothstein and Sabel propose. Dialogue may be difficult because one person's fair and transparent rules are another's rigid and inhumane system. Thus, the policy debate is not just about the impact of the past on the present, but also about how the state should be structured. Rules and laws need to be seen as fulfilling valid functions, not as arbitrary impositions by unresponsive outsiders. If people feel that their own views are being ignored, they may distrust government. For example, a study of community activists and welfare beneficiaries in Australia found that their distrust of government 
was founded on a belief that government did not trust them to articulate their own needs and to manage programs designed to benefit the community (Peel, 1998).18

The enforcement process must also be viewed as fair. Otherwise, the positive feedback loops outlined by Levi will not operate, and the attempt to establish rules and enforce them may backfire. Those who might have complied out of a sense of altruism or citizen duty may operate in a narrow self-interested way or even turn their resentment at the system into collective action designed to undermine the rules (Frey 1997b, Kahan 2001).19 For example, Bruno Frey (1998) finds that higher levels of tax enforcement did not increase Swiss tax collections and that offers to pay citizens to accept hazardous waste in their communities are counterproductive. Work on tax compliance in the United States suggests that a sense of duty and trust in government are more important than deterrence policies in explaining compliance. However, these results are difficult to interpret because most people are very poorly informed about the actual probabilities of audit (Scholtz 1998). In Minnesota, when a sample of taxpayers was sent a letter telling them that the audit probability was one, low and middle income taxpayers increased their tax payments compared with a control group.20 The threat of being discovered and punished did have an impact.

Probably, the best interpretation of these results is that reciprocal trust between government agencies and individuals can produce positive results, but that credible enforcement needs to be in place as a backup. Enforcement priorities and penalties, however, need to be publicized and broadly acceptable to the citizenry. Under these conditions, trust is not based on empathy or love but on mutual respect. Government may trust citizens to administer public programs or pay taxes because it believes that citizens will not rely on interpersonal empathy in deciding how to comply with public responsibilities. The state is more likely to devolve authority to local groups if it believes that narrow favoritism can be avoided.

18As Gambetta (1988:220) notes:

coercion exercised over unwilling subjects - who have not pre-committed themselves to being prevented from taking certain courses of action or who do not accept the legitimacy of the enforcement of a particular set of rights - while demanding less of our trust in others, may simultaneously reduce the trust others have in us. It introduces an asymmetry which disposes of mutual trust and promotes instead power and resentment. As the high incidence of paranoid behaviour among dictators suggests, coercion can be self-defeating, for while it may enforce 'cooperation' in specific acts, it also increases the probability of treacherous ones: betrayal, defection, and the classic stab in the back.

19The dynamic here is very similar to that outlined by Bruno Frey (1997a, 1997b) who argues that establishing a market in certain goods and services may undermine altruistic motivations to donate to provide these same benefits.

20High income taxpayers lowered their payments, but it seems difficult to see this as a reflection of a loss of moral commitment. The authors make the following argument. If audited, one's ultimate tax liability will be positively related to one's reported income because tax collectors are not perfectly informed. However, one is more likely to be audited the greater one's underpayment. These effects pull in opposite directions. However, if the audit probability is one, only the first effect operates (Slemrod, Blumenthal and Christian 2001). 
In relating democracy and trust, I have highlighted the tension between interpersonal trust based on empathy for particular individuals and the creation of a state whose citizens expect fair treatment from each other and from public officials. People who trust each other to obey the rules also trust others not to favor their friends and relations when that conflicts with their civic responsibilities. This is not to say that democracies do not value family ties and friendship but only to point out that a commitment to liberal democracy implies a commitment to rule-based, reliable state institutions that screen out most types of affect-based, reciprocal trust.

To proceed with the discussion of trust in the reliability and fairness of government agents, I consider an important case where such trust breaks down. If officials are corrupt, they betray the trust bestowed on them by the citizenry and act in the way that favors those who make payoffs and those with whom they have a reciprocal trusting relationship. Understanding the incentives for corruption and the ways it can be controlled help one see how government legitimacy might be achieved without a moral transformation of the population.

\section{Economizing on Virtue: The Control of Corruption}

Untrustworthy elected officials and bureaucrats are frequently corrupt. They substitute private benefits for public responsibility. If officials are generally untrustworthy, ordinary people and businesses may believe that the only way to get what they need is through a payoff. Furthermore, if most officials are known to be corrupt, people may seek things to which they are not entitled, such as tax breaks or waivers of costly regulations. Officials, in turn, may create extra rules, regulations, and contracting opportunities in order to profit personally. Politicians may demand payoffs in return for passing laws or issuing regulations, and they may even threaten to promulgate restrictive laws if not paid to desist. Corruption is a coping strategy for citizens facing untrustworthy, dishonest officials, but it may also be part of a conscious private-wealthmaximization strategy orchestrated by these same officials.

Paradoxically, a deeply corrupt regime usually operates with a high degree of reciprocal, affect-based trust. Because bribers and bribees are operating outside the law, they need to trust each other in order to maintain their relationships. They may design schemes that minimize the possibilities of betrayal, such as making payments only when corrupt services are delivered, or that limit the costs of betrayal, such as the use of middlemen. Nevertheless, the risks that one side will betray the other can be substantial so that links based on kinship or friendship can be important ways to lower the risk. The corrupt official is an untrustworthy and dishonest agent of the public interest but a trustworthy friend and relative.

To understand corruption one needs to clarify what is being bought and sold in a corrupt transaction. It will do little good simply to deplore the small number of trustworthy officials and the citizenry's willingness to pay. Instead, one needs to understand the incentives for making and accepting payoffs. Reforms can then be directed in two directions. First, one may reduce the opportunities and the net financial benefits of giving and receiving bribes and illicit campaign contributions. Second, one can try to shift the attitudes of politicians, public officials, and citizens away from personalized corrupt relationships toward the view that the state has obligations to the citizenry to provide fair and efficient service. For officials, this means replacing particularized, affect-based service delivery with fair and impartial state institutions. Officials become trustworthy agents of the state, not trustworthy friends and relations. For citizens, this means a willingness to 
demand more of the state than they have in the past. Thus, this second reform direction involves both changes in public attitudes toward government and the creation of institutions that can channel public demands for government reform.

My aim here is not to provide a full analysis of the problem of corruption.21 Instead, I first outline both the economic functions that corruption serves for those who pay bribes and the costs that it imposes on society. Reforms can then be designed to reduce the incentives both for those who pay and for those who accept or demand payoffs. Such reforms take people's underlying psychology as given and ask how behavior can be modified. Second, I consider how to structure the relationship between citizens and the state so that oversight by citizens can affect the trustworthiness of officials and their accountability to the public. Here, the anticorruption agenda is part of overall efforts to increase democratic legitimacy by improving the transparency of government actions and by increasing the role of citizens beyond simply voting for the parties and candidates of their choice.

\section{Economic Incentives for Corruption}

All states, whether benevolent or repressive, control the distribution of valuable benefits and the imposition of onerous costs. The distribution of these benefits and costs is generally under the control of agents who possess discretionary power. These agents are either bureaucrats with obligations to superiors or politicians who are meant to be agents of the public. Private individuals and firms who want favorable treatment may be willing to pay these agents. The problem arises from the fact that the payee is an agent. The agent is responsible to a principal whose goals will seldom line up with those of the "paying customer." Payments are corrupt when they are illegally made to public agents with the goal of obtaining a benefit or avoiding a cost. These payments are not merely transfers. Like legal prices, they affect the behavior of both payers and recipients. They violate the trust placed in officials by their superiors and the general public.

Six broad, sometimes overlapping, categories capture the most important incentives for corruption. (1)The government bureaucracy may be charged with allocating a scarce benefit to many individuals and firms using legal criteria other than willingness to pay. (2) Officials in the public sector may have little incentive to do their jobs well, given official pay scales and the level of internal monitoring. (3) Private firms and individuals seek to reduce the costs imposed on them by governments in the form of taxes, customs duties, regulations.(4) Governments frequently transfer large financial benefits to private firms through procurement contracts, privatizations, and the award of concessions. (5) The judiciary has the power to impose costs and transfer resources between litigants. (6) Elected politicians can accept illegal payoffs both to fund their campaigns and to enrich themselves. They may, in turn, pay off voters. I consider each briefly.

First, governments frequently provide goods and services for free or sell them at below market prices. In modern welfare states, these services include such basic services as health care and education. Bribery is a way of distributing these scarce services to those with the highest willingness-to-pay. Corruption of this type has several possible negative consequences. First, the

21For more comprehensive analyses that include more references to the existing literature see Rose-Ackerman (1978, 1999). 
goals of a program may be undermined if the services are provided only to those with the highest willingness to pay, excluding the needy or the well-qualified. Bribes may permit unqualified people and firms to obtain a benefit. Students might pay to alter the results of university admission tests, or people might pay doctors to declare them eligible for disability payments. Andre Shleifer and Robert Vishny (1993: 601) call this case "corruption with theft". Clearly, the unqualified will often have the highest willingness to pay since they have no legal way to obtain the service. Second, corrupt markets are likely to differ from open competitive ones. Because of the illegality of bribery, information about bribe-prices will not be well publicized, and prices may be sticky because of the difficulty of communicating market information. Some potential participants may refuse to enter the market because of moral scruples and fear of punishment, and public officials may themselves limit their dealing to insiders and trusted friends. A corrupt system may be not only less competitive but also more uncertain than a legal market. Furthermore, many officials can exercise monopoly power by determining the quantity of services provided. The corrupt official, like a private monopolist, may seek to supply less than the officially sanctioned level or seek to provide an increased supply if the government has set the supply below the monopoly level. Officials may have sufficient monopoly power to create scarcity even when the service is not scarce, either by delaying or withholding benefits unless paid bribes (Rose-Ackerman 1999: 9-38). Incentive-based reforms in this area would involve the elimination of policies with no justification based on efficiency or distributive justice, the streamlining of other programs to limit discretion, and the introduction of legally-imposed fees to allocate scarce benefits where allocation to high bidders will not undermine program goals. Sometimes the administrative system can be reorganized to limit the monopoly power of officials and give citizens more choices (RoseAckerman 1999: 39-52). Alternatively, corruption may arise because the government's commitments, to universal health care, for example, are inconsistent with the level of funding it provides. The state must either cut back its stated commitments or increase spending at the same time as it reforms the delivery system.

Second, bribes can be incentive payments to induce public officials to work hard. For example, firms and individuals may pay to avoid delay. Payoffs to those who manage queues can be efficient since they give officials incentives both to favor those who value their time highly and to work quickly. But the conclusion that the routine corruption of those who manage queues can be tolerated is extremely problematic. Although bribes can sometimes be characterized as incentive payments to public officials, a policy of active tolerance is likely to be destructive of the prospects for long-term reform. Payoffs that are widely viewed as acceptable should be legalized, but not all "incentive pay" schemes will actually improve bureaucratic efficiency. Instead, the civil service system of recruitment, pay and promotion may need reform to align the incentives of officials with the goals of the programs they are administering (Rose-Ackerman 1999: 69-88). Furthermore, law enforcement may need to be reformed to improve its deterrent effect. Too often, enforcement is used as a way to punish political opponents or is otherwise ineffective as a deterrent (ibid.: 52-58)

Third, individuals and firms pay bribes to avoid regulations, supersede the criminal law, and lower taxes. The impact of these payoffs depends upon the efficiency of the underlying programs that are subject to corrupt distortions. Given an inefficient legal framework, payoffs to avoid regulations and taxes may increase efficiency. This defense of payoffs is sometimes espoused by investors in the developing world and the countries in transition. It is a pragmatic justification that grows out of frustration with the existing legal order. It attempts to justify 
corruption carried out to obtain benefits to which one is not legally entitled.

But individuals and firms are not only obligated to obey laws that they judge to be efficient and just. In the United States, industry's response to environmental, health, and safety rules that it finds burdensome is not generally to bribe officials or enlist the help of criminals to evade the law. Instead, firms work to change the laws in Congress, make legal campaign contributions, lobby public agencies, and bring lawsuits that challenge laws and regulations. One can complain about the importance of wealth and large corporations in American political life, but, at least, well-documented lobbying activities and campaign contributions are superior to secret bribes in maintaining democratic institutions. Reform efforts here can involve the same kinds of programmatic and administrative reform outlined above, but they can also involve efforts to change attitudes and to provide transparent legal routes for efforts to influence political and bureaucratic processes.

Fourth, corrupt payments to win major contracts, concessions, and privatizing companies are generally the preserve of large businesses and high level officials. Such payoffs appear analogues to cases in which government disburses a scarce benefit, only this time the value of the benefit is valued in many millions, not a few thousand dollars. In the post-socialist states the most important recent cases involve the privatization of the entire capital stock of the economy. This is a massive, ongoing effort that produced many allegations of corruption and insider deals involving high level politicians and officials. In such cases, politically-connected officials may be effectively insulated from prosecution and can thus be less restrained in their corrupt demands than low-level bureaucrats. They may distort overall public spending priorities in the search for private gain. Furthermore, corruption introduces uncertainties into the economic environment that may give the corrupt firm an inefficiently short-run orientation. There are two reasons for this. First, the firm may fear that those in power are vulnerable to overthrow because of their corruption. A new regime may not honor the old one's commitments. Second, even if the current regime remains in power, the winner may fear the imposition of arbitrary demands once investments are sunk. Competitors may be permitted to enter the market, or the contract may be voided for reasons of politics or greed.

Reform in this area requires one to recognize that corruption is a two-sided affair involving both top politicians and business firms, both domestic and global (Rose-Ackerman 1999: 42-44,5968). Some firms that engage in legal political activities at home feel less constrained about violating laws on campaign funding and bribery in developing and transitional economies. Thus, considerable current effort is focusing on encouraging the international business community to develop norms of honesty and a lack of tolerance of bribery by their employees (Rose-Ackerman 2002). In addition to efforts that are essentially hortatory, the Organization for Economic

Cooperation and Development has a Convention on Combating Bribery of Foreign Public Officials in International Business Transactions that is in the process of ratification and includes some follow-up monitoring. The international movement to limit corruption in international business spearheaded by the nonprofit Transparency International is clearly an effort to change the level of honesty of global corporations.

Fifth, consider the role of the judiciary. Judges have power to affect the distribution of wealth through their decisions. Thus, like any public official with similar powers, they face corrupt incentives. Payoffs can be a way to speed up decisions when delays and backlogs are high. Bribes can also influence decisions in one's favor. Occasionally bidding wars have been reported in which 
parties on opposing sides compete in making payoffs. If the judiciary is viewed as corrupt, this introduces uncertainties into the business climate. The law on the books may not mean much, and those with disputes will avoid bringing them before the courts unless they are certain to be the high bribers. Individuals with disputes find ways to circumvent the court system by hiring private arbitrators and using other methods, such as the protection provided by organized crime. Others simply avoid certain kinds of deals or transact only with relatives or a few trusted colleagues. Reform of the judiciary can have spillover effects for the level of honesty and trust in other sectors of the economy.

Finally, democratic political systems must find a way to finance political campaigns without encouraging the sale of politicians to contributors. Governments have drawn the line between legal and illegal gifts in quite different ways, and legal frameworks vary greatly in the limits they place on quid pro quo deals by politicians. Even entirely legal contributions from wealthy interests are a source of concern. The worry is favoritism. Groups that give funds to elected officials expect help in the legislative process. They may also expect special treatment on individual problems in dealing with the bureaucracy or in seeking privatizing firms and public contracts. The electoral process can discipline politicians to represent the interests of their constituents, and voters may penalize candidates who seem too deeply beholden to special interests. But voters cannot act unless they know both how their representatives behave and who has given them money. Legal gifts can have a corrupting effect if they need not be made public and if the quid pro quo is not obvious to voters.

Conflicts of interest are a problem in many political systems. Potential conflicts exist whenever a politician or a member of his or her family or staff has an ownership interest in a firm that does business with the government or that can benefit from state policy. No corrupt payoffs or campaign donations may occur, but the risk of favoritism is the same. Politicians may seek to benefit businesses in which they have a financial interest. Thus, reciprocal trust between politicians and their friends can work against the creation of a legitimate democracy. Conversely, officials might use their influence in a private business to further their political careers. Selfdealing has only recently raised questions in some countries. In new democracies, conflicts of interest have not been a high priority for reformers. Yet, if uncontrolled, politicians with widespread business interests can undermine governmental legitimacy as surely as those who do the bidding of large contributors. In the former socialist countries, such as Russia and Poland, the problem is particularly acute because many newly privatized firms are controlled by their former managers who often remain active in politics (Collins 1993: 326).

The problem of money in politics is not limited to pressures on politicians. On the other side of the equation are inducements given to voters. A particularly intractable form of political corruption occurs when politicians accept illegal campaign contributions and then use them to pay off the voters on an individual basis. Voters may not object to the politicians' methods of campaign finance because they benefit from the largesse of candidates. The personalized nature of the benefits given to voters by incumbents can make it particularly difficult for credible opposition candidates to arise. The nation is nominally a democracy, but the constraints imposed on politicians' acceptance of payoffs are attenuated. Instead of a system based on democratic principles, the government is a structure of mutual favor-giving that benefits those with the most resources and the biggest mutually-reinforcing networks of trusted friends and supporters. 


\section{Citizens as Monitors of the State 22}

Now let us turn from the specific causes of corruption to consider how the public can be a check on corrupt public officials outside of the electoral process. These reforms depend upon the existence of citizens who believe that it is their duty to demand honest and trustworthy government. Martyrs and saints are always in short supply, but less altruistic people may be willing to engage in civic activities if the private costs are not too high and the promised social benefits are large.

Citizen monitoring can only operate if the government provides information on its actions. Citizens also must have a convenient means of lodging complaints and be protected against possible reprisals. Government officials must find it in their interest to respond to complaints. There are two basic routes for public pressure -- collective complaints by groups of citizens concerning general failures of government and objections raised by particular individuals against their own treatment at the hands of public authorities. In this section, I briefly canvass the features of an institutional environment designed to facilitate public accountability outside the ballot box. The package includes public information provision, a free media with weak libel law protection for public figures, avenues for individual complaints, and laws that facilitate the establishment and funding of nonprofits organizations,. The aim is to give officials reason to move from making decisions based on a mixture of personal ties and personal financial gain to making decisions in a fair and impartial manner. The goal to move government from a system of mutual favor-giving based on reciprocal trust to one where one-sided trust prevails -- that is, a system where citizens trust officials to follow the rules.

A precondition for lodging complaints is information. People need to know what they can expect from honest officials and how to make a complaint. In new democracies, such informative material represents the first time ordinary citizens have ever heard that they have rights against public authority. In addition to basic information on official standards of behavior, citizen activists need more comprehensive information.

Government must tell citizens what it is doing by publishing consolidated budgets, revenue collections, statutes and rules, and the proceedings of legislative bodies. Financial data should be audited and published by independent authorities such as the General Accounting Office (GAO) in the United States or the Audit Commission in Great Britain. Sometimes governments collect a good deal of information on their own operations but do not routinely make it public. In such cases, statutes that give citizens a right to gain access to this information can be an important precondition for effective public oversight. These laws permit citizens to obtain government information as members of the public without showing that their own personal situation will be affected. Exceptions protect privacy, internal memorandums, and the integrity of ongoing prosecutions. But a freedom-of-information act has little value if government does not gather much information. Many countries must first put information systems in order, provide for the publication of the most important documents, and assure public access to other unpublished material.

22Derived from Rose-Ackerman (1999: 162-174) 
Even a government that keeps good records and makes them available to the public may operate with impunity if no one bothers to analyze the available information -- or if analysts are afraid to raise their voices. There are three routes to accountability. If the aim is to pressure government to act in the public interest, the role of both the media and organized groups is important. If the goal is government accountability to individuals, avenues for individual complaints must be established.

The media can facilitate public discussion if it is privately owned and free to criticize the government without fear of reprisal. Government can also keep the press in line through advertising, printing contracts, and payments to journalists. Another subtle form of control is to overlook underpayment of taxes by editors and media companies, retaining the possibility of prosecution as a threat. In many countries restrictive libel laws give special protections to public officials. This is just the reverse of what is needed. Politicians and other public figures should be harder to libel than private citizens, not easier. They should not be immune from facing charges of corruption, and allegations of libel should be handled as civil not criminal matters. In this at least, the United States provides an outstanding example with a law that makes it more difficult to libel public figures than private individuals and that treats libel as a civil offense. Those in the public eye have assumed the risk of public scrutiny and have access to the media to rebut accusations.

A free media with good access to government information is not likely to be a sufficient check. The media may focus on lurid scandals and may have no real interest in reforms that would reduce the flow of corruption stories. Individuals and groups must push for change.

Individuals, acting alone, may be able to trigger government enforcement efforts. Controlling the dishonesty of low-level bureaucratic corruption is in the interest of top officials who may try to enlist ordinary citizens in the effort. This can be done without organized citizen activity if individuals can lodge complaints easily and without fear that corrupt officials will take revenge. Some bribes are made to get around the rules, and others are made to get a benefit that should have been provided for free. Facilitating complaints will only help uncover the latter type of corruption. Bribes that permit illegal activities or that soften a legal regulation or tax assessment are unlikely to be revealed by private individuals and firms unless they have been arrested and are seeking to mitigate their punishment. In contrast, if bribery demands are a condition for obtaining a legal benefit, individuals may not go along if they can appeal to an honest forum.

Many countries have established Ombudsmen to hear complaints of all kinds, not just those related to malfeasance. These offices can help increase the accountability of government agencies to ordinary citizens. Hence, they may generate a great deal of resistance from politicians and bureaucrats. Although this is regrettable, one should have modest expectations for an Ombudsman. These officials seldom uncover large scale systemic corruption and generally lack authority to initiate lawsuits. Some public agencies have created "hot lines" for direct citizen complaints. This method will only be successful, however, if complainants can preserve their anonymity or do not fear reprisals. "Hot lines" must be more than just symbolic. Public officials-the Ombudsman, agency oversight units, or law enforcement agents-- must follow up on complaints in a visible way. At the same time, if the complaints concern individuals, the accused must have a credible way of defending against false accusations. Otherwise, an anticorruption campaign can degenerate into a collection of private vendettas with people enlisting the state to settle their private feuds. 
Routes for individual complaints are not sufficient because individuals face a familiar free rider problem. Information may be available, but no one may have an incentive to look at it. The scandals uncovered by investigative journalists may provoke outrage, but no action. In short, there are limits to relying on complaints from individuals as the main route for public input and monitoring. More organized options are necessary such as the use of nonprofit organizations (NPOs) that help monitor government and work to improve its functioning.

Unfortunately, much research conflates the nonprofit sector with Robert Putnam's "civil society." This is a fundamental misunderstanding that has created considerable confusion. Putnam himself does not make this mistake, and in his discussion of social capital in the United States he goes out of his way to make clear that he is not much interested in nonprofits that survive on monetary donations and public subsidies and that rely primarily on paid staff. His interest is in volunteering and in the process of self-governance and inter-personal interactions that for him are the generators of social capital (Putnam, 2000). Putnam and his followers claim that volunteering in nonprofits builds trust that, in turn, builds democracy. I have already expressed my skepticism about these claims. Accepting this skeptical view, however, does not mean that the nonprofit sector is unimportant. Putnam ignores key functions that the sector can serve in a democracy.23 The nonprofit sector can play a direct role in helping to create a society where honesty and trust are the norm. Organizations with professional staff that are funded by members and wealthy donors can be of central importance in the development of an accountable, democratic state and of a market economy that operates within certain standards of fair dealing. Putnam's singing clubs and bowling leagues are less important under this view than organizations such as independent schools, soup kitchens, shelters for the homeless, and environmental or human rights advocacy groups.

An NPO's role may be explicitly political or policy-oriented. It may support candidates for office or lobby for particular policies such as environmental control, consumer product safety, the prevention of drunk driving, agricultural subsidies, worker rights, oil industry tax breaks, and so on. Such groups may be grass roots membership organizations, but they are likely to need professional employees who focus on the political process. They need to raise funds from members or large donors. Citizens' initiatives at the local level operating with no national umbrella organization frequently arise in democracies, but if the issues they focus on are of widespread concern, they are likely to organize at a higher level for more effective pressure. Some groups are explicitly or implicitly associated with political parties, but many groups are non-partisan. These groups are a necessary part of democracy that can aid public accountability over and above the accountability provided by the ballot box. They are not primarily producers of generic social capital but are, instead, direct checks on state power.

If one accepts this argument for the nonprofits as advocates and monitors of the democratic process, then the state needs to make it easy to establish formal nonprofit organizations. Some governments, worried that nonprofits will be used for monitoring purposes, limit such groups or make it very costly for them to organize. Formal legal constraints may be high, and members may be subject to surveillance and harassment. For example, Transparency International, an international NPO committed to fighting corruption worldwide, has found that setting up local

23See Rose-Ackerman (1996) and James and Rose-Ackerman (1986) for an overview of work in economics on the role of the nonprofit sector. 
chapters can be difficult even if local people are eager to organize a chapter. In some countries several years have passed without the chapter obtaining a formal charter. Once registered, nonprofits may face onerous formal reporting requirements.

Another problem is cooptation by the state. Some nonprofits provide services such as health care, education, and housing. Their financing may be provided by the state or by aid funds administered by the state. Thus their very existence depends upon cooperation with public authorities. As a consequence, they may be reluctant to criticize officials openly. To avoid such tensions, an NGO that takes on an anticorruption mandate should avoid participation in service delivery.

The World Values Survey found that organizational membership may contribute to democratic change.24 One would like, however, to know more about how this happens. The sector's impact ought to depend upon the kinds of groups that attract members. My own hypothesis would be that policies that encourage the development of those nonprofits that interact with government can help institutionalize democracy but that nonprofits that simply build "social capital" through sports, recreation and cultural activities will not, on their own, have much impact.

$* * * * *$

Corruption is commonly associated with untrustworthy and dishonest government officials. It underlying cause is the search for private economic gain on both sides of the transaction. It represents a betrayal of public trust. Corruption can be controlled by lowering the benefits and raising the costs of particular corrupt transactions. But it can also be controlled indirectly by limits on political power and by changes in public attitudes toward the exercise of that power. This latter strategy involves giving people and groups a way to complain about poor government service provision. To facilitate such activities, the government supplies information about its actions, the media and the public voice complaints, and private organizations and individuals push for public accountability. The goal is to increase governmental openness, leaving it more vulnerable to popular discontent. Thus, many regimes, even nominally democratic ones, may view such policies with suspicion. They are, nevertheless, an essential check on corruption and on other forms of dishonest self-dealing that can arise if officials are insulated from popular oversight. One route to a more trustworthy state is the creation of institutions empowered to hold officials to account over and above criminal investigations for malfeasance. My presumption is that a trustworthy state is encouraged by organized demands for accountability from skeptical but well-informed citizens.

\section{Trust and the Transition from Socialism}

Both theory and empirical work in advanced democracies suggest that attempts to produce generalized trust are not likely to produce large gains in terms of democratic performance and market functioning. Rather, the fundamental requirement is to create and maintain state and market

24 The list of organizations in the WVS includes labor unions, political parties and professional associations as well as all kinds of community groups and organized nonprofits (Inglehart 1997: 396). 
institutions that are reliable and trustworthy and that are not undermined by interpersonal relations based on mutual trust (or distrust). Strong, loving interpersonal bonds are, of course, valuable aspects of any society, but they can cause harm if they operate unchecked within political and bureaucratic organizations.

The problem of institution building is central to the ongoing transition process in the postsocialist countries of Central and Eastern Europe. The transition has created special strains (RoseAckerman 2001). Democratization may breed corruption and crime if it is accompanied by a weakening of state controls and confusion among the population about proper behavior in a context of increased freedom. Similarly, the shift from central planning to the market may lead to monetary corruption as a replacement for the system of administered benefits based on connections. The market replaces many former administrative decisions, but the state remains a source of important benefits and costs (Miller, Grødeland, and Koshechkina 2001, Rose-Ackerman 1994). A key issue for reformers is to identify particular sources of strain and to act to prevent transitional problems from producing major long-term distortions.

An important tension arises in the post-socialist countries. They need to create trustworthy modern organizations to exercise state power and private economic activity, but doing so may undermine older reciprocal methods of coping. Research on the possible tension between trust in rules and reciprocal trust between people is central to understanding the problems faced by the post-socialist countries. Of particular concern are situations where personal links undermine reform efforts. Russians and Central and East Europeans established dense networks of informal connections to cope with the difficulties of life under socialism and some of these practices have continued as ways to cope with the present situation (Rose 1999:10, Ledeneva 1998). One question raised by the transition is whether the legacy of these informal connections is helping or hindering the process of institutionalizing democracy and the market.

\section{The Citizen and the State}

As the transition proceeds, people are beginning to view government as having obligations to its citizens, and they are becoming more willing to complain if treated poorly. In surveys in Central and Eastern Europe, ordinary people complain about corruption and red tape. Corruption is maintained both by officials who create problems and ask for payments to resolve them and by citizens who seek individualized benefits and who do not think that others will condemn them. However, people's dissatisfaction with the status quo suggests that there are no deep cultural barriers to reform; change will accompany reforms in the service delivery system and in people's realistic expectations of the behavior of others (Rose-Ackerman 2001). 25

Unfortunately, at present, reciprocal expectations of corruption and self-dealing are creating a vicious cycle in some of the countries in Central and Eastern Europe. They are in a trap where widespread non-compliance and lack of government credibility create self-reinforcing patterns of behavior in spite of people's expressions of distaste for the present situation. Fortunately, this dynamic does not operate everywhere. There appear to be widespread differences across the post-

25 These findings are consistent with Margaret Levi's model of "contingent consent" (Levi 1997:16-30). 
socialist countries in the functioning of the state and the market and in the degree of trust in public institutions and in other people. Most of the countries created out of the Soviet Union appear to suffer from much higher levels of distrust and corruption and much lower levels of functioning than many of the countries on the list for potential European Union membership. In the worst case, some countries and sectors risk descending into vicious cycles in which corruption, distrust, and dishonesty breed more of the same over time. Conversely, virtuous cycles may begin to operate in which trust and honesty build on each other. These patterns depend both on people's underlying attitudes and on calculations of self-interest broadly understood. Countries that are experiencing vicious cycles in some areas of public life obviously face much more serious reform challenges than those that seem to be evolving toward state and market structures similar to those in industrialized countries.

Corruption in public services, especially education and health, is beginning to have negative consequences for the poor especially in the countries of the former Soviet Union. There is a trend to de facto privatization of some services that, without any compensating subsidies for the poor, is reducing their options. According to the World Bank, under-the-table payments to teachers are jeopardizing universal school enrollment in some of the poorest countries, especially in Central Asia. Of course, poverty itself encourages families to keep children at home as income earners, but the need for payoffs is an added incentive (World Bank 2000b: 42-43, 236). For health care as well, payoff demands mean that the poor are badly served and that illness can further impoverish families. World Bank sponsored surveys of ten countries between 1996 and 1999 found that "informal payments" were common and are on the rise (ibid.: 47, 262-266). As the World Bank notes, this result "reflects a collapsed public system that is now financed on a fee-for-service basis"(ibid: 264). The privatization of land and the distribution of pensions and social benefits also sometimes involve corruption and favoritism, and the poorest households are usually the ones that lose out. Police corruption means that law enforcement services are biased toward those willing pay (ibid: 47-48). In short, the widespread corruption of government service provision has a particularly harmful effect on the poor and appears to be contributing to the population's disaffection with and distrust of the political regimes in some of the post-socialist countries especially in the former Soviet Union.

In the democracies of Central Europe the problems are not so dire, and most seem headed toward more competitive democratic structures and functioning market economies. In those countries the problems of distrust, dishonesty and corruption vary across sectors. In general, three issues need to be addressed. First, the public administration needs to become more open to public scrutiny and influence outside of the electoral process. Such an opening up must be done with care to avoid its capture by wealthy private interests (Hellman, Jones, and Kaufmann 2000).

Nongovernmental organizations may need some help to get organized; information on state activities must be widely available; and the public administration and the courts need reform to accommodate a more open system. Second, the legislative process also would benefit from more transparency and stronger conflict-of-interest rules. The issue of political party and electoral financing needs to be addressed to limit the impact of private wealth. Third, the problem of lowquality and corruptly provided public services is likely to be a growing problem as GDP per capita rises above pre-reform levels. In Central Europe some sectors under heavy state control appear to be becoming de facto privatized through "informal payments" and self-dealing. The response might be de jure privatization, but if issues of distributive justice, market failure, and fairness are 
involved, the state ought not exit entirely from sectors such as health care and higher education. It will have to organize the delivery of services to provide social safety nets and assure broad access. A wealthier population will demand high quality services and will pay, either legally or illegally, to obtain them. Unless the state is willing to accept the glaring disjunction between its claims of universal service and the reality of "informal payments", it will need to carry out massive overhauls of these sectors as the economic recovery proceeds.

\section{The Legacy of the Past}

To understand the transition process in the post-socialist countries, one needs to distinguish between problems that are the result of the transition itself and those that are rooted in the socialist past. Sorting out the multiple causes for the current problems will help political leaders to design solutions. Yet, the impact of the past on levels of trust in government is unclear. In surveys, people do not generally blame the Communists for current problems. In particular, the current high level of corruption in society is generally viewed either as part of the moral crisis of transition or as a result of the country's culture (Miller, Grødeland, and Koshechkina, 2001, 141). Current perceptions of the impact of the prior regime may not be the whole story, however. As Piotr Sztompka (1999:152-160) argues, today's citizens of the countries of Eastern and Central Europe grew up under the "bloc culture" of the socialist system, an experience that eroded trust in public institutions and may have contributed to the high levels of corruption during the transition. Sztompka argues that during the socialist period people segmented their lives into the public and the private with the former seen as "bad" and the latter as "good." There was a generalized distrust of any information originating with the public authorities, and authorities were viewed as alien, hostile, and not to be trusted.

Research on Poland in the seventies found that people praised those who "beat the system" even by illegal or illicit means (id.: 156). Sztompka characterizes the Solidarity movement as an attempt to create a political movement using the rhetoric of family, based on strong interpersonal ties and mutual trust based on bonds that were nationalistic, religious, and rooted in working class solidarity. The regime was the object of distrust (id.:157-158). A survey in 1988 found that $88 \%$ blamed economic and social problems on "bribery, corruption and abuse of power for private benefits" (cited by Sztompka 1999:159). Two years later, when the first democratic government took power, there was both horizontal trust among people and vertical trust of the Solidarity-led government. This temporary surge of trust in government, however, broke down as economic conditions deteriorated. Distrust in state authorities reappeared and grew over time (id: 159-160). In short, although Poland went through a short post-revolutionary period of trust in government, the reemergence of distrust in authorities and the perception of widespread corruption may be a function not only of economic hardship but also of people's past experience with government under Communist rule.

Most countries in transition are still suffering economic hardship and negative or static growth rates so it may be too early to measure trends except in those countries where negative spirals are under way in which high levels of corruption and distrust breed even higher levels in the next period. Poland, however, has begun to experience positive growth rates in national income, and although not all sectors of society have benefited, it can be used as a laboratory to examine the interaction between trust in government and economic prosperity. Drawing on survey evidence, 
Sztompka notes that at the end of 1993 one could interpret the Polish situation pessimistically as one where distrust was breeding even more distrust producing a spiral of cynicism, cheating, and law evasion. Yet, according to more recent work, this is not what happened. Polish society seems to have turned a corner. In the second half of the nineties levels of trust in parliament, government, the President, and the Church have risen and maintained themselves at quite high levels. Support for democracy has risen from 32\% in 1993 to $72 \%$ in 1998. Sztompka explains the shift in attitudes as arising from six factors. They are the perceived irreversibility of the transition, the consolidation of democracy and constitutionalism, the consolidation of the market and private property accompanying a surge in economic growth, inclusion in Western European institutions such as NATO, the growth in civil society and an educated middle class, and generational turnover (Sztompka 1999: 179-190).

Some of the results from other surveys, however, suggest that Sztompka's report on trends may be too optimistic. In Poland, the level of trust in political institutions is no better than in the region as a whole and has not improved over time except for trust in the president (Mishler and Rose 1998). In short, even in Poland, the survey results are not all rosy. One would like to know, however, if the recent declines in approval for the current regime reflect overall disillusionment or simply growing political sophistication including a greater willingness to challenge the regime and demand accountability (Hardin 1999). Do the numbers represent disillusionment that may lead to apathy, or do they represent a realism about politics that may produce more active grassroots reform efforts? This question raises a basic empirical puzzle in interpreting survey results on trust and attitudes toward public institutions. One sign of a well-established democracy is a citizenry willing to question government actions and to hold politicians and other officials to account. In surveys, citizens in established democracies may seem more discontented, distrusting, and skeptical of government than those in more authoritarian or less competitive systems. This can be a danger sign if the public also feels disempowered and apathetic about politics. However, it can be a sign of strength if it translates into a willingness to challenge unjustified exercises of political power.

\section{Business in Weak Legal Environments}

Business firms in Eastern and Central Europe operate in an environment where corruption is common, legal standards are often unclear, and the judiciary is unreliable. Reciprocal trust between market actors may be a substitute for one-sided trust in legal rules. However, when the law is weak, reciprocal trust may be difficult to maintain outside of existing links based on kinship and history. This fact will make it difficult to establish competitive markets, and limit the ability of buyers and sellers to expand their base of suppliers and customers. In extreme cases, a country can spiral into deeper and deeper economic crisis. Statelbusiness relations are important not just for the economy, but also for the legitimacy and competence of government. If the relationship is one riddled with corruption, favoritism, and dishonesty, both the state and the private business sector may be viewed with distrust by members of the public.

The broad differences in corruption and protection payments between Russia and Ukraine, on the one hand, and Central Europe, on the other, extend into the economic sphere. In surveys, formally-organized firms in Russia and Ukraine are much more likely to admit to hiding sales and salaries than firms in Central Europe (Johnson, Kaufmann, McMillan, and Woodruff 2000, Table 
1). Wholly off-the-books enterprises are also reported to be more common in Russia and Ukraine, and such firms hide all of their output. Furthermore, firms in Russia and Ukraine report spending more time on government and regulatory matters than elsewhere (18\% and $25 \%$, compared with about $10 \%$ for the other countries)(id., Table 2). This may be a rough measure of the degree of extortion to which firms are subject and the degree to which firms can be exempted from rules if they curry favor with authorities. In Russia and Ukraine almost all firms report making illicit payments, and they hide a high proportion of their sales.26 In Central Europe, a group of firms also operates both corruptly and partly off-the-books, but the practice is not so widespread.

Surveys demonstrate how firms manage to cope when the legal system is weak. Informal relationships built on trust and private sanctions exist but cannot easily bear the entire burden of maintaining business deals. Weak states produce widespread corruption, private protection rackets, and the flouting of regulatory and tax laws. The countries of Eastern and Central Europe vary in the security of property rights, and countries with more secure property rights have higher levels of new investment by established firms (Johnson, McMillan, and Woodruff 2000b, 2000c).27 The security of property rights is measured by the ability of the state to enforce its own rules impartially. In other words, the benchmark is not a libertarian state but one that provides services, regulates behavior, levies taxes, and operates an impartial court system. Property rights are taken to be less secure if bribery and protection payments are common and if the courts do not enforce contracts. Thus, corruption is not the route to a secure relationship with the state but opens up possibilities for extortion. Furthermore, if firms pay for protection, either to private mafias or to the police, this reduces the security of rights as well (Johnson, McMillan, and Woodruff 2000b, Table 1). One-sided trust in the state as a reliable actor seems important. Firms appear willing to substitute legal and impartially administered taxes for the uncertainties of bribe payments and the dangers of relying on private protection services (Friedman, Johnson, Kaufmann, Zoido-Lobaton 2000).

Taking the condition of the legal system and level of corruption as given, how do firms cope? In the face of a weak legal environment, developing a trustworthy reputation through repeated dealings can provide an imperfect substitute. There are important differences between the countries in Central Europe, on the one hand, and Russia and the Ukraine, on the other. Central Europeans are more likely to claim that the courts can enforce contracts. However, they are more likely to report a dispute and if they have one, they are less likely to use the courts (Johnson, McMillan, and Woodruff 2000a, table 1). It appears that the Central European economies are moving toward a system in which reliable legal background norms enforced by the courts are helping to create market systems where strangers can deal with each other with an acceptable level

26 The average percentage of sales not reported is $29 \%$ for Russia and $41 \%$ for the Ukraine. In Central Europe the percent of sales not reported ranges from $5.4 \%$ to $7.4 \%$.

27Entrepreneurs with the least secure property rights invest $40 \%$ less than those with the most secure property rights. At the time of the survey in 1997, the absence of bank finance did not prevent firms from investing since they were profitable enough to satisfy their investment needs internally (Johnson, McMillan, and Woodruff 2000b). Although employment growth is unrelated to property rights, high sales growth is significantly associated with more secure property rights (Johnson, McMillan, and Woodruff 1999b). 
of risk. Reciprocal trust appears to be created over time as former strangers began to deal with each other. In contrast, in Ukraine and Russia the reliability of the courts and the law is low and hence economic actors are reluctant to deal with outsiders. Both buyers and sellers are locked into mutually reinforcing relationships that may limit disputes, but also limit competition and entry.

In general, an impartial, reliable legal system that sustains transactions between strangers ought to facilitate the development of a market economy. However, during the transition process there may be a downside. As McMillan and Woodruff's work on Mexico and Vietnam demonstrates, a reliable legal system ought to make entry and exist easier. Unfortunately, the possibility of exit may make it more difficult to establish trusting relationships based on repeat play (Johnson, McMillan and Woodruff 2000a; McMillan and Woodruff 1999a, 1999b; Woodruff 1998; Wintrobe 1995). Legal reform may destroy old reciprocal trusting relations more quickly than it permits new ones to arise. In the process, existing producers may suffer -- a possibility that will lead them to resist reform in the first place. Thus, the transition from one system to the other may well be painful and costly for incumbents who suffer not only a decline in monopoly profits, but also the obsolescence of accepted methods of monitoring performance. In the transition, the system of interpersonal monitoring may break down before the "rule-of-law" becomes established.

The results discussed above cover only small and medium-sized enterprises. The managers of large firms with close links to top political leaders are not included in the sample. Such large firms may not have secure property rights in the legal sense but may be able to obtain favored treatment because of their insider status. A World Bank study calls this "state capture" and documents its importance in the transition economies (Hellman, Jones, and Kaufmann 2000; World Bank 2000a). The main risk facing such firms is the risk of a change in the political leadership. The World Bank study attempted to measure the extent to which institutions of state power had been captured. Once again, there were important differences between the states of the former Soviet Union and those farther to the west. This research suggests that bribery and extortion are mostly a problem for medium-sized businesses. Large dominant firms have established close relationships with top political leaders so that mutually beneficial deals are possible. These deals are often harmful to the overall growth and prosperity of the country and undermine efforts to establish the legitimacy and trustworthiness of the state. Researchers need to go beyond the issues of corruption and informal methods of coping to understand the trusting, mutually-reinforcing ties between top state officials and wealthy private interests.

It seems clear that the problems of corruption and untrustworthy government are more serious in the former Soviet Union than elsewhere. Some countries are experiencing problems that seem to be different in kind from the problems of others farther to the west. I raise for discussion the possibility that Russia, Ukraine and other parts of the former USSR may need to go through a second transition that moves them from a trap where corruption and distrust breed more of the same and businesses take refuge in a small number of relationships with trusted suppliers and customers. These countries need to create a more law-bound economic system that emphasizes the creation of well-functioning markets. Incremental change from the status quo may not be sufficient to shift the most dysfunctional economies onto a sustainable upward growth path. 


\section{Conclusions}

Three major policy issues need better documentation and analysis. The first is the generally lower levels of trust and higher levels of perceived corruption as one moves east across the region. These results suggest that some countries are experiencing high levels of government failure and are in danger of spiraling downward to lower levels of government performance and economic growth. Second, even in countries that have escaped such pathologies, there are worrying suggestions of disillusionment. Some sectors have lagged behind, especially those such as health, education, and infrastructure where state provision remains important. These are sectors where corruption, "informal payments," and discontent seem high. Third, we need to locate and analyze the remaining lacuna in the creation of a state viewed as politically legitimate by its citizens.

This paper is essentially a plea for research that brings together work on honesty, trust, and corruption, respectively, and uses this scholarship to study the process of transition in Central and Eastern Europe. Within that broad body of work, I believe that the most fruitful research would focus on particular sectors and particular types of interactions between people and between people and institutions, both public and private. Generalized trust in other people and in institutions may, indeed, have deep cultural and historical roots, but even if that is so, marginal changes in attitudes and behavior are still important. These marginal changes may depend upon estimates of the trustworthiness of other people and upon the institutional frameworks in which they operate. Reciprocal trust can either complement or undermine one-sided trust in the reliability of institutions. The transition process in Central and Eastern Europe is full of both types of interactions. We need to understand when conflicts exist and face the unpleasant fact that strong interpersonal ties based on kinship and friendship are not always socially desirable. In modern societies, people need to be able to separate their roles as friend and relation from their roles as bureaucrat, politician, judge, employee, or business manager. 


\section{REFERENCES}

AKERLOF, George A., 1970. The market for lemons, Quarterly Journal of Economics, 84: 488-500.

AXELROD, Robert, 1984. The Evolution of Cooperation (New York, Basic Books).

BAIER, Annette, 1986. Trust and antitrust. Ethics, 96: 231-60.

BARBER, Bernard, 1983. The Logic and Limits of Trust (New Brunswick NJ, Rutgers University Press).

BOK, Sissela, 1978. Lying: Moral Choice in Public and Private Life (New York, Random House).

BRAITHWAITE, Valerie. 1998. Communal and exchange trust norms: their value base and relevance to institutional trust, in Valerie BRAITHWAITE and Margaret LEVI, (eds.), Trust and Governance (New York, Russell Sage).

BRAITHWAITE, Valerie, and Margaret LEVI, (eds.) 1998. Trust and Governance (New York, Russell Sage).

BREHM, John, and Wendy RAHN, 1997. Individual-level evidence for the causes and consequences of social capital, American Journal of Political Science, 41: 9991023.

COHEN, Jean, 1999. Trust, voluntary association and workable democracy: the contemporary American discourse of civil society," in Mark WARREN, (ed.), Democracy and Trust (Cambridge UK, Cambridge University Press).

COLLINS, Paul, 1993. Civil service reform and retraining in transitional economies: strategic issues and options, Public Administration and Development, 13:325-344.

DASGUPTA, Partha, 1988. Trust as a Commodity, in Diego GAMBETTA, (ed.), Trust: Making and Braking Cooperative Relations (Oxford, Basil Blackwell).

FEHR, Ernest, and Simon GÄCHTER, 2000. Fairness and retaliation: the economics of reciprocity, Journal of Economic Perspectives, 14:159-181.

FREIDMAN, T., Simon JOHNSON, Daniel KAUFMANN, and D. ZOIDO-LOBATON, 2000. Dodging the Grabbing Hand, Journal of Public Economics, 76: 459-493. 
FREY, Bruno S., 1997a. Not Just for Money: An Economic Theory of Personal Motivation (Cheltenham UK, Edward Elgar).

FREY, Bruno S., 1997b. A constitution for knaves crowds out civic virtue, Economic Journal, 107: 1043-1053.

FREY, Bruno S., 1998. Institutions and morale: the crowding-out effect, in Avner BEN-NER and Louis PUTTERMAN, (eds.), Economics, Values, and Organizations (Cambridge UK, Cambridge University Press).

GAMBETTA, Diego, 1988. Can we trust trust?, in Diego GAMBETTA, (ed.), Trust: Making and Braking Cooperative Relations (Oxford, Basil Blackwell).

GAMBETTA, Diego, 1993. The Sicilian Mafia (Cambridge MA, Harvard University Press).

HARDIN, Russell, 1998. Trust in government, in Valerie BRAITHWAITE and Margaret LEVI, (eds.), Trust and Governance (New York, Russell Sage).

HARDIN, Russell, 1999. Do we want trust in government? in Mark E. WARREN, (ed.), Democracy and Trust (Cambridge UK, Cambridge University Press).

HARDIN, Russell, 2001. Conceptions and explanations of trust, in Karen COOK, (ed.), Trust and Society (New York, Russell Sage).

HELLMAN, Joel S., Geraint JONES, and Daniel KAUFMANN, 2000. "Seize the State, Seize the Day": State Capture, Corruption, and Influence in Transition,(Washington DC, World Bank Policy Research Working Paper 2444).

INGLEHART, Ronald, 1997. Modernization and Postmodernization: Cultural, Economic, and Political Change in 43 Societies (Princeton NJ, Princeton University Press).

INGLEHART, Ronald, and Wayne E. BAKER, 2000. Modernization and cultural change, and the persistence of traditional values, American Sociological Review, 65: 19-51. 
JAMES, Estelle, and Susan ROSE-ACKERMAN, 1986. The Nonprofit Sector in Market Economies, Fundamentals of Pure and Applied Economics 9 (Chur, Switzerland, Harwood Academic Publishers).

JOHNSON, Simon, Daniel KAUFMANN, John MCMILLAN, and Christopher WOODRUFF, 2000. Why do firms hide? bribes and unofficial activity after communism, Journal of Public Economics, 76: 495-520.

JOHNSON, Simon, John MCMILLAN, and Christopher WOODRUFF, 2000a. Courts and Relational Contracts, draft, September 25.

JOHNSON, Simon, John MCMILLAN, and Christopher WOODRUFF, 2000b. Property Rights and Finance, draft, September 5.

JOHNSON, Simon, John MCMILLAN, and Christopher WOODRUFF, 2000c. Entrepreneurs and the ordering of institutional reform: Poland, Slovakia, Russia and Ukraine compared," Economics of Transition, 8: 1-36.

KAHAN, Dan M., 2001. Trust, collective action, and law," Boston University Law Review, 81: 333-345.

LEDENEVA, Alena V., 1998. An Economy of Favors: Informal Exchanges and Networking in Russia. (Cambridge UK, Cambridge University Press).

LEVI, Margaret, 1997. Consent, Dissent, and Patriotism, (Cambridge UK, Cambridge Univ. Press).

LEVI, Margaret, 1998. A state of trust, in Valerie BRAITHWAITE and Margaret LEVI, (eds.), Trust and Governance (New York, Russell Sage).

LUHMANN, Nicholas, 1979. Trust: a mechanism for the reduction of social complexity, in Trust and Power: Two Works by Nicholas Luhmann (Chichester, John Wiley and Sons).

LUHMANN, Nicholas, 1988. Familiarity, confidence, trust: problems and alternatives, in Diego GAMBETTA, (ed.), Trust: Making and Braking Cooperative Relations (Oxford, Basil Blackwell).

MANSBRIDGE, Jane, 1999. Altruistic trust, in Mark WARREN, (ed.), Democracy and Trust (Cambridge UK, Cambridge University Press). 
MCMILLAN, John, and Christopher WOODRUFF, 1999a. Dispute prevention without courts in Vietnam, Journal of Law Economics and Organization, 15(3): 637-658.

MCMILLAN, John, and Christopher WOODRUFF, 1999b. Interfirm relationships and informal credit in Vietnam, Quarterly Journal of Economics, 114: 1285-1320.

MCMILLAN, John, and Christopher WOODRUFF, 2000. Private order under dysfunctional public order, Michigan Law Review, 98: 2421-2458.

MILLER, William L., Åse B. GRØDELAND, and Tatyana Y. KOSHECHKINA ,2001. A Culture of Corruption: Coping with Government in Post-Communist Europe, (Budapest, Central European University Press).

MISHLER, William, and Richard ROSE, 1998. Trust in Untrustworthy Institutions: Culture and Institutional Performance in Post-Communist Societies, (University of Strathcylde, Glasgow, Scotland, Studies in Public Policy Number 310, Centre for the Study of Public Policy ).

OFFE, Claus, 1999. How can we trust our fellow citizens? in Mark WARREN, (ed.), Democracy and Trust (Cambridge UK, Cambridge University Press).

PEEL, Philip. 1998. Trusting disadvantaged citizens, in Valerie BRAITHWAITE and Margaret LEVI, (eds.), Trust and Governance (New York, Russell Sage).

PUTNAM, Robert D., with Robert LEONARDI and RAFFAELLA, 1993. Making Democracy Work: Civic Traditions in Modern Italy (Princeton NJ, Princeton University Press).

PUTNAM, Robert D., 2000. Bowling Alone: The Collapse and Revival of American Community (New York, Simon and Schuster).

ROSE, Richard, 1999. What Does Social Capital Add to Individual Welfare? A Empirical Analysis of Russia, (University of Strathclyde, Glasgow, Studies in Public Policy 318, Centre for the Study of Public Policy ).

ROSE, Richard, 2000. Russia Elects a President: New Russia Barometer IX, (University of Strathclyde, Glasgow, Studies in Public Policy 330, Centre for the Study of Public Policy ). 
ROSE, Richard, and Christian HAERPFER, 1998a. New Democracies Barometer V: A 12-Nation Survey, (University of Strathclyde, Glasgow, Studies in Pubic Policy 306, Centre for the Study of Public Policy ).

ROSE, Richard, and Christian HAERPFER, 1998b. Trends in Democracies and Markets: New Democracies Barometer 1991-1998., (University of Strathclyde, Glasgow, Studies in Pubic Policy 308, Centre for the Study of Public Policy ).

ROSE, Richard, and Doh Chull SHIN, 1998. Qualities of Incomplete Democracies: Russia, the Czech Republic and Korea, (University of Strathclyde, Glasgow, Studies in Public Policy 302, Centre for the Study of Public Policy).

ROSE-ACKERMAN, Susan, 1978. Corruption: A Study in Political Economy (New York, Academic Press).

ROSE-ACKERMAN, Susan, 1994. Reducing bribery in the public sector, in Duc V. Trang, (ed.), Corruption and Democracy (Budapest, Institute for Constitutional and Legislative Policy).

ROSE-ACKERMAN, Susan, 1996. Altruism, nonprofits, and economic theory, Journal of Economic Literature, 34: 701-728.

ROSE-ACKERMAN, Susan, 1999. Corruption and Government: Causes, Consequences and Reform (Cambridge UK, Cambridge University Press).

ROSE-ACKERMAN, Susan, 2001. Trust and honesty in post-socialist societies, Kyklos, 54: 415-444.

ROSE-ACKERMAN, Susan, 2002. 'Grand' corruption and the ethics of global business, Journal of Banking and Finance, forthcoming.

ROTHSTEIN, Bo, 2000a. Social Capital and Institutional Legitimacy, presented at the 2000 Annual Meeting of the American Political Science Association, Washington DC, August 31- Sept. 3.

ROTHSTEIN, Bo, 2000b. Trust, social dilemmas and collective memories, Journal of Theoretical Politics, 12: 477-501.

SABEL, Charles, 1993. Studied trust: building new forms of cooperation in a volatile economy, Human Resources, 46: 1133-1170. 
SCHOLTZ, John T., 1998. Trust, taxes, and compliance, in Valerie BRAITHWAITE and Margaret LEVI, (eds.), Trust and Governance (New York, Russell Sage).

SHLEIFER, Andrei, and Robert VISHNY, 1993. Corruption, Quarterly Journal of Economics, 108: 599-617.

SLEMROD, Joel, Marsha BLUMENTHAL, and Charles CHRISTIAN, 2001, Taxpayer response to an increased probability of audit: evidence from a controlled experiment in Minnesota, Journal of Public Economics, 79: 455484.

SLOVIC, Paul, 1993. Perceived risk, trust, and democracy, Risk Analysis, 13: 675-682.

STOLLE, Dietlind, 1998. Bowling alone, bowling together: group characteristics, membership, and social capital, Political Psychology, 19: 497-526.

STOLLE, Dietlind, 2001. Clubs and congregations: the benefits of joining an association, in Karen COOK, (ed.), Trust in Society (New York, Russell Sage Foundation).

SUGDEN, Robert, 1984. Reciprocity: the supply of public goods through voluntary contributions, Economic Journal, 94:772-787.

SZTOMPKA, Piotr, 1999. Trust: A Sociological Theory (Cambridge UK, Cambridge University Press).

USLANDER, Eric M., 2000-2001. Producing and Consuming Trust, Political Science Quarterly, 115: 569-590.

WARREN, Mark, (ed). 1999a. Democracy and Trust (Cambridge UK, Cambridge University Press).

WARREN, Mark, 1999b. Introduction, in Mark WARREN, (ed.), Democracy and Trust (Cambridge UK, Cambridge University Press).

WARREN, Mark, 1999c. Democratic theory and trust, in Mark WARREN, (ed.), Democracy and Trust (Cambridge UK, Cambridge University Press). 
WINTROBE, Ronald, 1995. Some economics of ethnic capital formation and conflict, in Albert BRETON, Gianluigi GALEOTTI, Pierre SALMON, and Ronald WINTROBE, (eds.), Nationalism and Rationality (Cambridge UK, Cambridge University Press).

WOODRUFF, Christopher, 1998. Contract enforcement and trade liberalization in Mexico's footwear industry, World Development, 26: 979991.

WORLD BANK, 2000a, Anticorruption in Transition: A Contribution to the Policy Debate, (Washington DC, The World Bank).

WORLD BANK, 2000b. Making Transition Work for Everyone: Poverty and Inequality in Europe and Central Asia (Washington DC, The World Bank). 